\title{
HOLOCENE MORAINES AND ROCK GLACIERS IN THE CENTRAL BEN OHAU RANGE, SOUTH GANTERBURY, NEW ZEALAND
}

\author{
By V. R. MaGregor* \\ (New Zealand Geological Survey, Lower Hutt, New Zealand)
}

\begin{abstract}
Young moraines and rock glaciers in the central part of the Ben Ohau Range, about $42 \mathrm{~km}$. south of the highest peaks of the Southern Alps, are briefly described. A new formation, the Ben Ohau Formation, consisting of the Ferintosh, Jacks Stream and Dun Fiunary Members, is proposed for moraines and rock glaciers believed to have been built since the climatic optimum by three minor glacial advances. Moraines, and outwash and fan gravels, deposited during a more extensive pre-climatic optimum advance which was contemporaneous with the Cockburn Glacial Phase (Cochrane) in North America are assigned to the Birch Hill Formation. The sequence of glacial advances recorded in the Ben Ohau Range is compared with that found in western North America.
\end{abstract}

RÉsumé. Moraines holocènes et glaciers rocheux dans le massif central Ben Ohau, Canterbury du sud, Nouvelle Zélande. On décrit brièvement des moraines récentes et des glaciers rocheux de la partie centrale du massif Ben Ohau, environ $42 \mathrm{~km}$ au sud des plus hauts sommets des Southern Alps. Une nouvelle formation, la Formation Ben Ohau, composée de Ferintosh, Jacks Stream et Dun Fiunary membres, est proposée pour les moraines et les glaciers rocheux que l'on pense s'être formés depuis l'optimum climatique par trois avances glaciaires mineures. Moraines, et graviers d'érosion et de cones d'éjection, déposés durant une avance optimum préclimatique plus étendue, contemporaine de l'époque glaciaire de Cockburn (Cochrane) en Amérique du Nord, sont assignés à la formation Birch Hill. La séquence des avances glaciaires rapportées dans le massif Ben Ohau est comparée à celle trouvée dans l'ouest de l'Amérique du Nord.

Zussammenfassung. Holozäne Moränen und Blockgletscher in der zentralen Ben Ohau Range, Sül.Canterbury, Neuseeland. Junge Moränen und Blockgletschern im zentralen Teil der Ben Ohau Range etwa $42 \mathrm{~km}$ südlich der höchsten Gipfel der Southern Alps werden kurz beschrieben. Zur Einordnung von Moränen und Blockgletschern, deren Entstehung durch drei kleinere Gletschervorstösse nach dem Klimaoptimum angenommen wird, wird die Einführung einer neuen Formation, der Ben-Ohau-Formation, vorgeschlagen, die wiederum in die Ferintosh-, Jacks Stream- und Dun Fiunary-Stadien untergliedert ist. Moränen, Sanderflächen und Schotterfächer, die während eines grösseren Vorstosses vor dem Klimaoptimum gleichzeitig mit dem Cockburn-Stadium (Cochrane) in Nordamerika abgelagert wurden, werden der Birch Hill-Formation zugeordnet. Die Serie der in der Ben Ohau Range festgestellten Gletschervorstösse wird mit der im westlichen Nordamerika gefundenen verglichen.

\section{INTRODUCTION}

The study of Quaternary glacial fluctuations in New Zealand has progressed rapidly in the last 15 years and a chronology of late Pleistocene glacial advances is now well established (see Suggate ( 1965 ) for a full list of references). Relatively little has been published on the moraines built since the last Pleistocene advance, the Kumara-3 advance in the standard New Zealand chronology. The best known of the young moraines are those built by glaciers on the eastern side of the Southern Alps in the Tasman valley and its larger tributaries (Fig. I). Young moraines are well-developed and well-preserved in some smaller tributary valleys in the ranges east of the Main Divide of the Southern Alps. Separation of these moraines from one another is perhaps clearer than in the main valleys, because the gradients of the valleys are steep and the oscillations of the glacier termini were large relative to the size of the moraines. In I96I the writer studied young moraines and alluvial fans on part of Lilybank station, north of Lake Tekapo and about $5^{\circ} \mathrm{km}$. north-east of the Ben Ohau Range (McGregor, unpublished). In 1962 young moraines in the central and eastern parts of the Ben Ohau Range were examined (Fig. 2). The Ben Ohau Range lies between the Tasman and Dobson Rivers and south of the highest part of the Southern Alps. The moraines examined are in the valleys radiating from the central part of the range in the vicinity of the highest peak, Dun Fiunary

* Present address: Mineralogisk Museum, København, Denmark. 


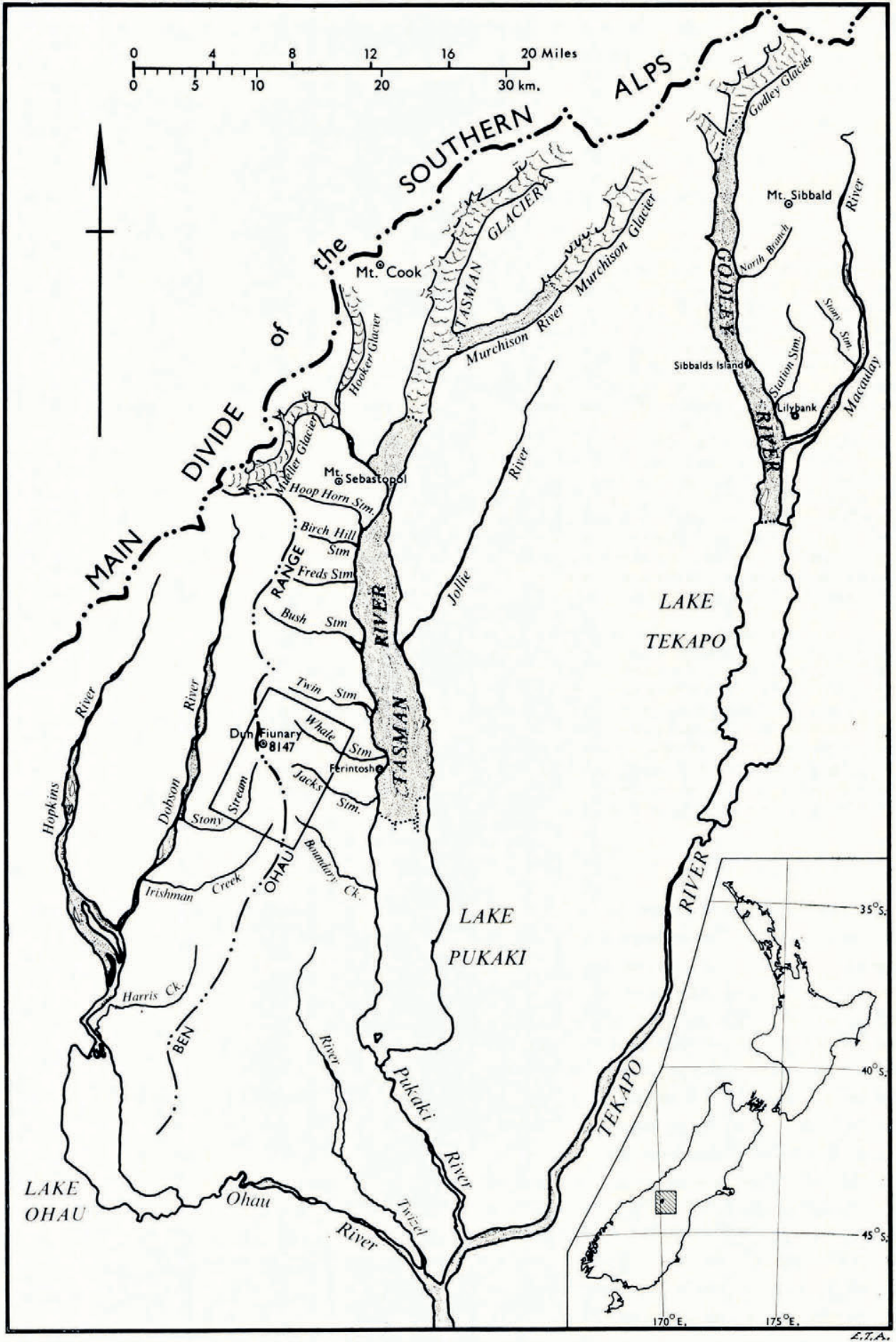

Fig. I. Location map of the area south and east of the highest part of the Southern Alps, South Island, New Zealand 


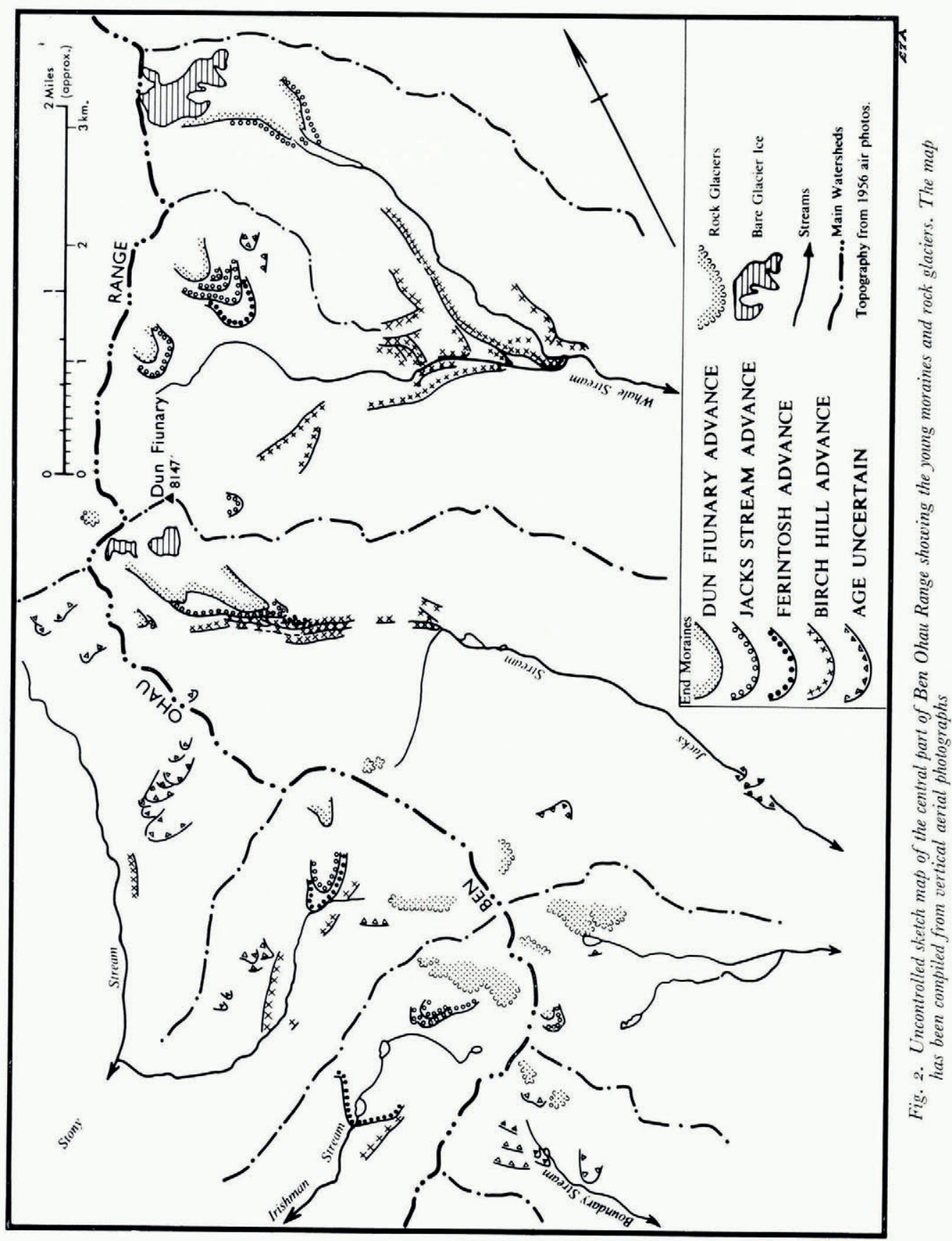


$(2,484 \mathrm{~m}$.). Twin, Whale and Jacks Streams flow east into the Tasman River, and Stony and Irishman Streams flow west into the Dobson River. The moraines are built mostly of metagreywacke, arkosic sandstone and argillite, all strongly indurated.

\section{Nomenclature}

Rock-stratigraphic nomenclature is used here in the same way as in Suggate's (I965) account of the late Pleistocene geology of the northern part of the South Island, where the New Zealand late Pleistocene glacial chronology is based. The moraines and rock glaciers of the central Ben Ohau Range have been grouped on the basis of relative position, weathering of surface materials, preservation of morphology and extent of vegetation cover into two new formations, the Birch Hill and Ben Ohau Formations. The latter comprises the Ferintosh, Jacks Stream and Dun Fiunary Members. The Birch Hill Formation includes morainic deposits, outwash gravel and fan gravel. The Ben Ohau Formation contains only morainic and rock-glacier deposits, the latter being restricted to the Dun Fiunary Member. With further field work it will probably be possible to include talus deposits in the formation and correlate them with one or other of the members. This study has been concerned less with deposits than with their topographic expression as moraines, rock glaciers, outwash terraces and alluvial fans, and in the rest of the paper the geology is described in these terms.

\section{Birch Hill Formation}

Speight ( 1963 ) described the late Quaternary glacial geology of the Tasman valley area using a geomorphic mapping unit, the landform association. He distinguished five landform associations, each formed by a separate glacial advance. The fourth, the Pukaki Landform Association, which was formed by the last major ice advance in the area, was correlated with the Poulter advance of north Canterbury. This, in turn, is correlated with the Kumara-3 advance, which ended about 14,000 yr. ago (Suggate, 1965). The deposits of Speight's youngest unit, the Birch Hill Landform Association, are here called the Birch Hill Formation. The type area for the formation is the same as that for the landform association: "the walls of the Tasman valley from Mount Sebastopol to south of the Jollie River confluence". In the Tasman valley the front of the Birch Hill glacier reached a position approximately one-third of the way from the front of the present glacier to the terminal moraines of the Pukaki Landform Association. End moraines in Twin, Whale (Fig. 3), Jacks, Stony and Irishman Streams are correlated here with the type Birch Hill Formation on the grounds that they are the only important moraines between those of the Pukaki Landform Association and those clustered around the glaciers near the heads of the valleys, and that the degree of modification of their surfaces resembles that of the type moraines. Outwash terraces related to the Birch Hill moraines were recognized in Freds, Twin and Whale Streams. In the Tasman valley, and Twin and Whale Streams, there are two sets of moraines, the older of which is referred to here as Birch Hill I and the younger as Birch Hill II. The Birch Hill II moraines are the more massive. On the western side of the Tasman valley the Birch Hill I moraines are first recognizable between Hoophorn and Birch Hill Streams whence they descend obliquely down the steep valley side to flatter ground between Freds and Bush Streams. The Birch Hill II lateral moraines lie below those of Birch Hill I. They extend from Mount Sebastopol to a little south of Freds Stream and constitute a wide terrace on the flatter ground south of Birch Hill Stream. Both sets of terminal moraines have been destroyed or buried beneath the outwash of the Tasman River. Glaciers in all valleys north of Bush Stream reached the Tasman valley during Birch Hill I time. During Birch Hill II time the glaciers in Hoophorn and Birch Hill Streams may not have reached the main valley and the one in Freds Stream certainly did not. None of the Birch Hill glaciers in the tributary valleys south of Bush Stream reached the Tasman valley. In all the valleys visited there are moraines, sometimes, as in Twin and Whale Streams (Fig. 3), rather massive ones, correlated with Birch Hill II. In Twin and Whale Streams there 


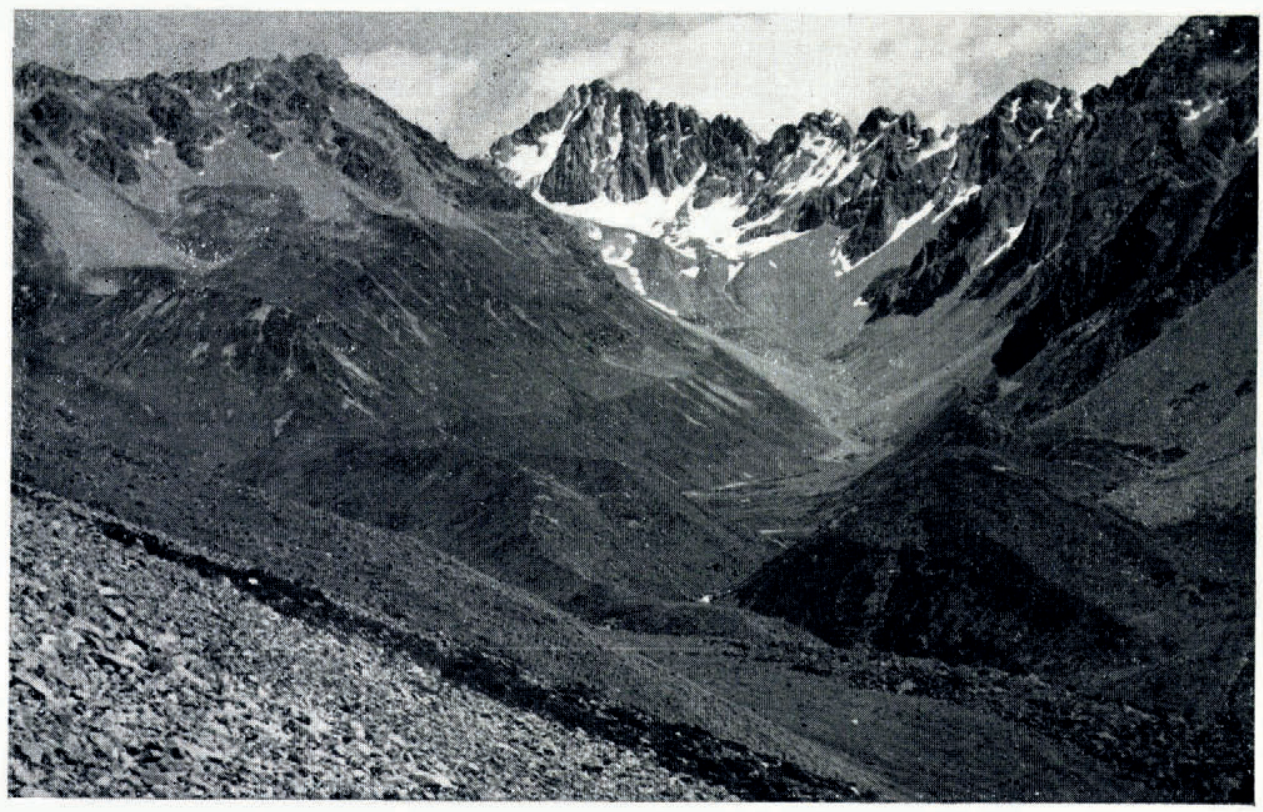

Fig. 3. Birch Hill II moraine loop at the fork in Whale Stream, Ben Ohau Range. The high terrace above the moraine loop at the left probably indicates the level of the Birch Hill I glacier. The moraines higher in the valley behind the Birch Hill II loop were built mainly during the Facks Stream advance, but they were also reached by ice during the Dun Fiunary advance

are remnants of Birch Hill I moraines that are much more affected by stream erosion than the Birch Hill II moraines in the same valleys, and outwash terraces related to them. In Twin Stream the stream from the front of the Birch Hill II glacier flowed in a channel cut deeply into the Birch Hill I outwash. This suggests that there may have been a warmer period with strong stream erosion between the building of the two sets of moraines.

The characteristics of the Birch Hill moraines are summarized in Table I. They are usually

Table I. Principal Charagters of Moraines

Birch Hill

Formation

Relative positions of moraines

Modification of moraine surfaces

Destruction of moraines by streams

Vegetation

Additional

characters
Usually separate from Ben Ohau group

Cover of loess smooths the surface

Commonly partly destroyed, especially in the larger valleys Complete cover except blocks or surfaces eroded later Commonly two sets of moraines

\section{Ben Ohau Formation
Ferintosh Member $\quad$ Jacks Stream Member}

Dun Füunary Member

Usually form a close-spaced group with Dun Fiunary moraines enclosing remnants of glaciers

Rounded crests; slopes stabilized; no
loess

Breached in some Rarely breached valleys

20-50 per cent cover

Only scattered low

The least massive moraines
Appear pale grey from a distance; argillite blocks on the surface broken into fragments; pinkweathering crust on arkosic sandstones
Often bulky and sharp-crested; probably ice-cored: slopes not stabilized

Rarely breached

Almost no vegetation

Appear dark grey from a distance; argillite blocks on the surface unbroken; no pink-weathering crust on sandstones 
clearly separated from the moraines of the three members of the Ben Ohau Formation. The surfaces of the Birch Hill moraines are often covered with loess, which may be $\mathrm{I} \mathrm{m}$. or more thick where the moraines are exposed to dust-laden winds from the north-west.

\section{Correlatives of the Birch Hill Formation}

Suggate (196r) correlated the Birch Hill moraines in the Tasman valley with the Waiho moraine loop near the Franz Josef Glacier on the western side of the Southern Alps. The writer has seen a remnant of a terminal moraine, which is probably the same age as those of the Birch Hill Formation, in the Hopkins valley, west of the Ben Ohau Range. On Lilybank station, north of Lake Tekapo, there are well-preserved Birch Hill moraine loops in all the larger tributary valleys south of Mount Sibbald, lateral moraines and a remnant of a terminal moraine (Sibbalds Island) in the Godley valley, and a well-preserved end-moraine complex in the Macaulay valley, where the double nature of the Birch Hill advance is clear. Birch Hill I is represented by lateral moraines and a thin layer of till, dotted with large blocks, spread out in front of the massive Birch Hill II terminal moraine. The Birch Hill I till overlies a layer of peat containing wood fragments. Mr. A. C. Beck has collected a sample of wood from this peat on which a radio-carbon date of $8460 \pm 120$ yr. B.P. (S8o/5o6; N.Z.548) has been obtained (personal communication from A. C. Beck). In North Branch, a tributary of the Godley River that flows south-west from Mount Sibbald, the Birch Hill Formation is represented by four lateral moraines set one above the other. Correlatives of the Birch Hill Formation will probably prove to be widespread in the higher ranges of the South Island.

\section{Ben Ohau Formation}

The Ben Ohau Formation includes all the morainic deposits in the Ben Ohau Range younger than those of the Birch Hill Formation, as well as other deposits built at the same time as the moraines. The type locality is at the head of Jacks Stream (Fig. 4) and the southern branch of Stony Stream (Fig. 5) with the former as the principal type locality. Stony Stream is included in the type locality because the boundary between moraines of the Birch Hill Formation and those of the oldest (Ferintosh) member of the Ben Ohau Formation is somewhat uncertain in Jacks Stream. The moraines can be separated into three distinct groups.

\section{Ferintosh Member}

The name Ferintosh Member is proposed for the oldest of the three moraine groups. It is taken from Ferintosh station, which includes the area drained by Whale and Jacks Streams. In Jacks Stream the moraine is covered by talus on one side of the valley and it is partly over-ridden by younger moraines. It is side by side with moraines correlated with the Birch Hill Formation and the boundary between the two is not certain. The Ferintosh end moraine in the southern branch of Stony Stream is clearly developed and well separated from the Birch Hill moraines. Single moraine loops correlated with the Ferintosh Member were found near the heads of Irishman Stream and the south fork of Whale Stream. Both are very low, and the moraine loop in Irishman Stream is closer to a moraine remnant tentatively correlated with the Birch Hill Formation than to the younger Ben Ohau moraines. The low nature of the loops suggests that, although the Ferintosh advance in these valleys was more vigorous than the Jacks Stream and Dun Fiunary advances, it may not have lasted as long. The characteristics of the Ferintosh moraines are summarized in Table I.

\section{Jacks Stream Member}

The type moraine of this member in Jacks Stream is very well developed on the south side of the valley, but it has been mostly covered by talus on the north side. It has been breached 


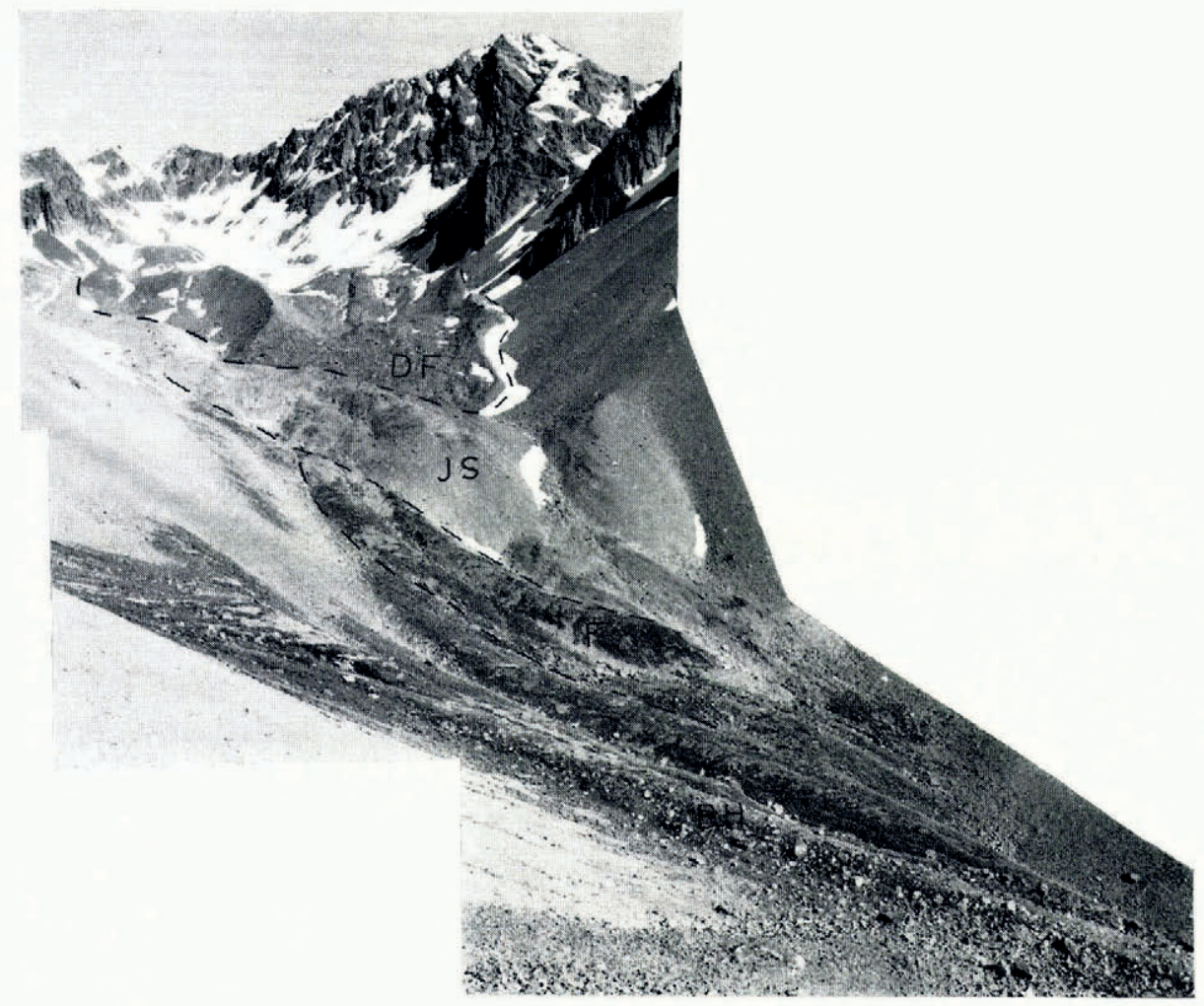

Fig. 4. Moraines of the Birch Hill Formation $(B H)$, and Ferintosh $(F)$, Jacks Stream $(7 S)$ and Dun Fiunary $(D F)$ Members of the Ben Ohau Formation in the upper part of Jacks Stream, Ben Ohau Range. The prominent peak to the right of the head of the valley is Dun Fiunary

by stream action. Other moraines correlated with the Jacks Stream Member were found near the heads of Freds Stream, both forks of Whale Stream, Stony Stream and Irishman Stream. The characteristic features of the moraines are given in Table I.

\section{Dun Fiunary Member}

The youngest moraines and rock glaciers belong to this member. The type locality is at the head of Jacks Stream where there is a very well-developed moraine loop at the foot of Dun Fiunary. The lateral moraines are high and sharp-crested, suggesting that they are icecored, while the terminal part is much lower. Moraines correlated with the Dun Fiunary Member are present in all the main valleys in the Ben Ohau Range north of Jacks Stream. In most of the valleys north of Whale Stream they are the only moraines younger than those of the Birch Hill Formation. South of Jacks Stream the member is usually represented by small, lobate rock glaciers, for instance in the cirques at the heads of Boundary Stream, Irishman Stream and the southern branches of Jacks and Stony Streams. The rock glaciers are very conspicuous on air photographs and they are quite different from the ice-cored moraines of the same age. They are all rather small and form the lower parts of talus accumulations below steep, south-facing rock walls. The rock glaciers consist of smooth loops of talus, whose down-hill faces are generally at the maximum angle of repose, piled one behind the other. 


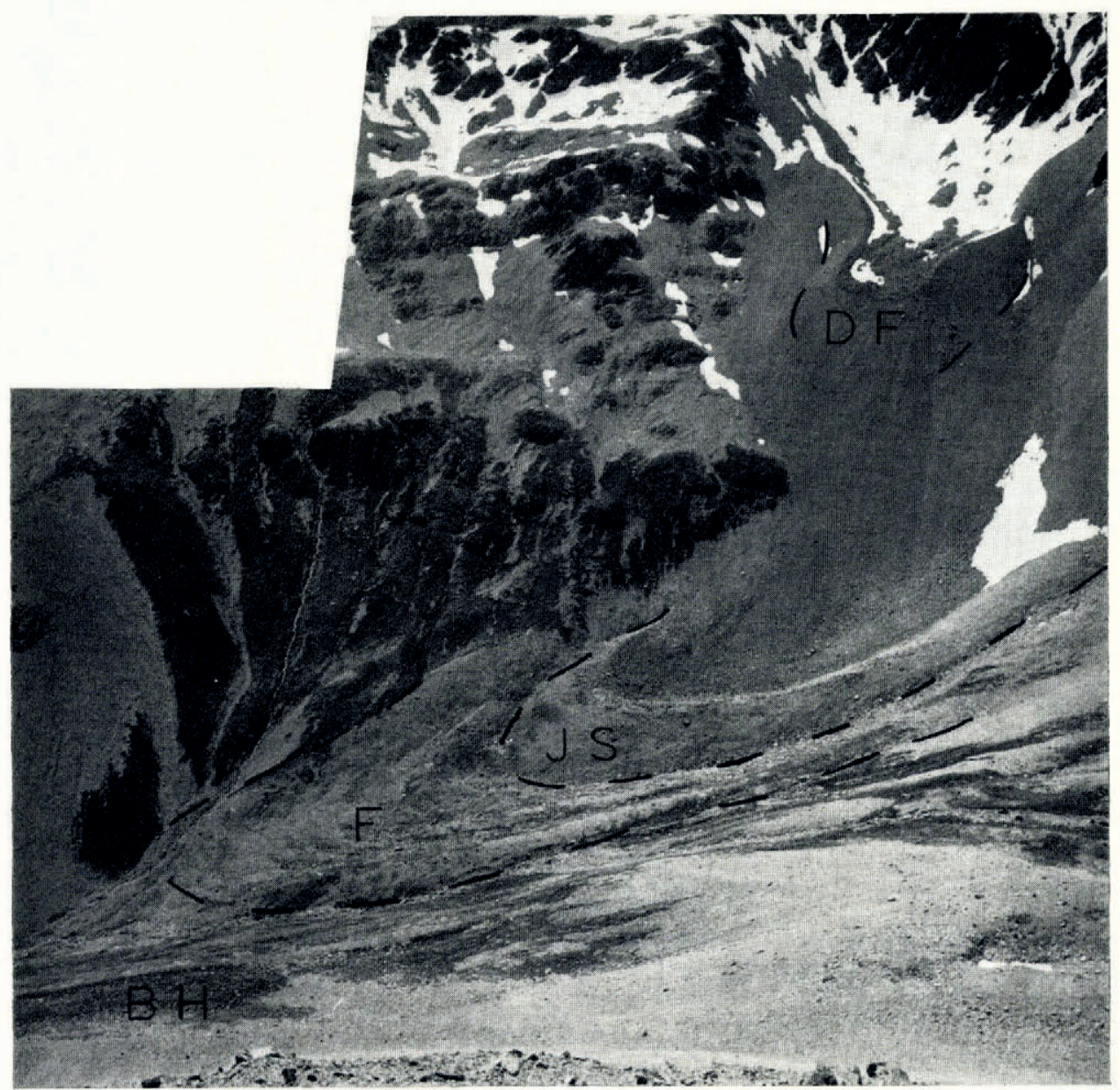

Fig. 5. Moraines of the Ferintosh (F), Jacks Stream (JS) and Dun Fiunary (DF) Members of the Ben Ohau Formation at the head of the south branch of Stony Stream

The characteristic features of the Dun Fiunary moraines are listed in Table I. A common feature is that they are high and sharp-crested, and that they are more bulky than the Jacks Stream and Ferintosh moraines in the same valleys. Østrem (1964) has demonstrated that young moraines in Norway with these characteristics are ice-cored, and it is probable that many of the Dun Fiunary moraines are also ice-cored. Dun Fiunary and Jacks Stream moraines in the same valleys can usually be distinguished with ease on aerial photographs or when seen from a distance because the former are much darker. This is probably because the blocks of black argillite on their surfaces are less weathered.

\section{Correlatives of the Ben Ohau Formation}

There are no moraines in the Tasman valley between the Birch Hill moraines and those that cluster around the snouts of Mueller, Hooker and Tasman Glaciers which have been described by McKellar (1955), Kolb (1958) and Lawrence and Lawrence (1965). The 
moraines as a whole can be correlated with the Ben Ohau Formation with reasonable certainty, but it is more difficult to correlate individual moraine loops with one of the members of the formation. The moraines around the larger glaciers support a denser cover of vegetation than corresponding moraines in the Ben Ohau Range because they are about 750 to I, $200 \mathrm{~m}$. lower in altitude and because the precipitation is higher closer to the Main Divide. Of the moraines built by Mueller Glacier, which are the best described, the Foliage Hill moraine remnant (see Lawrence and Lawrence, I 965 , fig. 4) is very tentatively correlated with the Ferintosh Member, the outer part of the White Horse Hill moraines is correlated with the Jacks Stream Member, and all the younger moraines, i.e. all the moraines built by the glacial advance that reached a maximum about 1740 and by minor oscillations during the retreat from this maximum, are correlated with the Dun Fiunary Member.

In the Lilybank area, correlatives of the Ben Ohau Formation were recognized only in North Branch (Fig. 6). About $1 \cdot 5 \mathrm{~km}$. up-stream from the Birch Hill moraines there is a well-preserved double moraine loop, partly covered by vegetation, which is correlated with the Ferintosh Member. Behind it and partly over-ridden by a large ice-cored moraine is a moraine loop correlated with the Jacks Stream Member. The ice-cored moraine is correlated

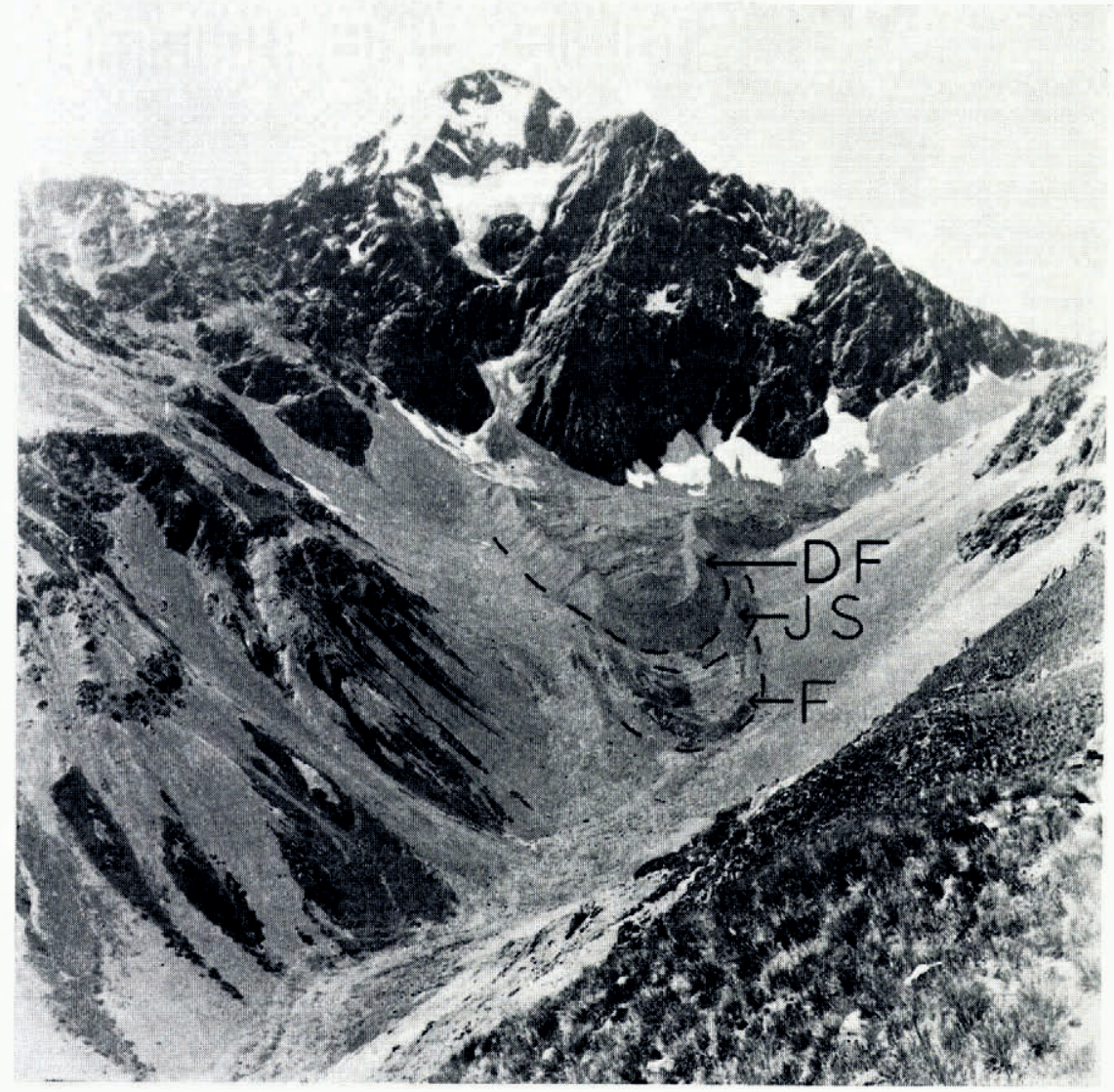

Fig. 6. Upper part of North Branch and the south face of Mount Sibbald, Lilybank station. The large ice-cored moraine of the Dun Fiunary $(D F)$ Member almost covers a small, bare moraine loop of the Jacks Stream $(\mathcal{Z} S)$ Member. In front of them is a double moraine loop, partly covered with vegetation, which is correlated with the Ferintosh $(F)$ Member 
with the Dun Fiunary Member. It extends about $900 \mathrm{~m}$. down North Branch from a large avalanche chute on the south face of Mount Sibbald and is bordered by a raised ridge within which is a sunken area with an irregular surface of mounds and hollows. Several of the hollows contain melt-water pools and this supports the idea that the moraine is ice-cored. Moraines corresponding to the older two members of the Ben Ohau Formation appear to be very uncommon or absent elsewhere in the Lilybank area and in the ranges between the Godley and Tasman Rivers.

\section{Age of the Moraines}

The date of $8460 \pm 120$ yr. B.P. on wood from beneath Birch Hill I till in the Macaulay valley probably represents a time shortly before the Birch Hill advance. This advance was therefore pre-climatic optimum and was probably contemporaneous with the Cockburn Glacial Phase in northern Canada during which an important system of end moraines, including the well-known Cochrane moraines, were built (Falconer and others, 1965). The maximum Holocene advances in Alaska (Karlstrom, I964; Porter, 1964) and in West Greenland (Weidick, in press) occurred during the same period.

The Birch Hill Formation is much more strongly modified by erosion and deposition of loess than the oldest moraines of the Ben Ohau Formation and it is therefore probable that the Birch Hill and Ferintosh advances were separated by a long warmer interval, i.e. by the climatic optimum. Thus the Ferintosh, Jacks Stream and Dun Fiunary advances probably all belong to the post-climatic optimum cooler period, which has been referred to as the Little Ice Age (Matthes, 1939) or the Neoglaciation (Sharp, 1960). Moraines built by Mueller Glacier that are correlated with the Dun Fiunary Member have been dated by Lawrence and Lawrence (1965), using tree-growth layers, as having been built by a glacial advance that reached a maximum about A.D. I 745. Lawrence and Lawrence (1965) also found that the outermost of the moraines correlated with the Jacks Stream Member is older than A.D. I 445 .

Two sets of post-climatic optimum moraines and rock glaciers have been found in many areas in the western United States. The younger moraines are unstable and very fresh, and they are clearly related to glaciers that have retreated or disappeared since the end of the last century. The older moraines are also fresh but they have been stabilized. They are between 3,500 and 2,000 yr. old at Mount Rainier, Washington (Crandell and Miller, 1964), and about 2,80o yr. old in the La Sal Mountains, Utah (Richmond, I962). Three sets of young moraines have been found in parts of the Sierra Nevada and they have all been considered post-climatic optimum (Harrison, 1956; Birman, 1964). However, the relation of the oldest set of moraines described by Birman, those of the Hilgard glaciation, to the two younger sets resembles the relation of the Birch Hill moraines to the Ben Ohau moraines. In Alaska three major sets of post-climatic optimum moraines have been recognized by Porter (1964) in the Brooks Range and by Karlstrom (1964) on the Kenai Peninsula. The oldest moraines in the Brooks Range are about 2,80o yr. old. The oldest moraines on the Kenai Peninsula were built by three glacial advances that occurred about 4,000, 3,000 and 2,000 yr. ago, respectively. The next moraines were built about A.D. I 000 and the youngest set after A.D. I 500. The writer is less familiar with the literature on post-climatic optimum moraines in other parts of the world.

The sequence of Holocene glacial advances recorded in the Ben Ohau Range is very similar to that found in western North America, especially Alaska, where the record is most complete. The timing of glacial events during the last $220 \mathrm{yr}$. (Lawrence and Lawrence, 1965; unpublished manuscripts of Professor D. B. Lawrence) and during the earlier Holocene was very similar in New Zealand and North America, and it seems likely that it was similar, too, in the time in between. Consideration of the North American dates suggests that the Ferintosh moraines might be about 2,800 yr. old, and the Jacks Stream moraines about I,00o yr. old. 


\section{Glacial Advances and Climatic Implications}

The moraines described above are believed to have been built by distinct glacial advances that occurred during four periods of climatic deterioration that involved cooling, increased precipitation and/or other factors. The pattern of glacier variation in other parts of the world within the period represented in the Ben Ohau Range by the Dun Fiunary advance suggests that the maximum advance of the glaciers within each period may have occurred at different times in different valleys. The discontinuities in such characteristics as weathering and vegetation cover between the four groups of moraines suggest that the periods of climatic deterioration were separated by periods of climatic amelioration when the glaciers retreated and may have disappeared from many valleys. There may have been shorter phases of climatic amelioration and the glaciers may have advanced and retreated more than once with each period of climatic deterioration. Only moraines built after the maximum advance and not reached by later advances would have been preserved. The evaluation of these possibilities must wait until the moraines can be dated, and in this paper the three post-climatic optimum advances have been described as if each was a simple advance to a maximum that was contemporaneous over the whole area.

The degree of modification of the Jacks Stream moraines resembles that of the Dun Fiunary moraines much more than that of the Ferintosh moraines and it is probable that the period of climatic amelioration inferred between the Jacks Stream and Dun Fiunary advances was shorter than that between the Ferintosh and Jacks Stream advances. This, again, was certainly shorter than that between the Birch Hill and Ferintosh advances. Nevertheless, there is good evidence that the glaciers retreated and in at least some valleys disappeared altogether after the Jacks Stream advance, and that the lowest moraines of the Dun Fiunary advance were built at the maximum of an actual re-advance of ice. This is clearest in the southern branches of Whale and Stony Streams. In Stony Stream (Fig. 5) the Jacks Stream glacier disappeared and a talus cone was built before the formation of the tiny glacier or firn bank of the Dun Fiunary advance.

The Ben Ohau Range lies in the rain shadow of the Main Divide of the Southern Alps. Most of the precipitation comes with winds from the north-west and there is a relatively rapid decrease in precipitation towards the south-east, away from the higher mountains. Snow lines during some of the young advances in the Ben Ohau Range were roughly determined by measuring the altitudes at which lateral moraines fade out up-valley, and it was found that the snow lines during each advance were generally lower in the valleys closer to the Main Divide.

During the Dun Fiunary advance rock glaciers formed in some valleys farther away from the Main Divide, while true glaciers formed in valleys closer to it. Wahrhaftig and Cox (I959) concluded that rock glaciers in central Alaska formed where the average annual temperature was below freezing point and ice could accumulate in the interstices of debris formed at the bases of steep shaded cliffs, but where the net accumulation of snow was insufficient for the formation of normal glaciers, i.e. under drier conditions than normal glaciers. The fact that rock glaciers formed in some valleys in the Ben Ohau Range during the Dun Fiunary advance shows that the climatic deterioration there involved cooling more than increase in precipitation. That rock glaciers formed while there were normal glaciers in the valleys closer to the Main Divide, together with the evidence that the snow line was lower closer to the Main Divide, indicates the same sort of precipitation/cloudiness gradient as the present one, i.e. that most precipitation came from the north-west. Large rock glaciers have been seen on aerial photographs of the south-eastern part of the Ben Ohau Range. If, as is thought probable, these date from the time of the Pukaki advance, then the same conclusions regarding climate probably apply to that time.

There are no moraines from the Ferintosh and Jacks Stream advances in the valleys north 
of Whale Stream except for Freds Stream, where there are moraines tentatively correlated with the Jacks Stream Member. It seems certain that these northern valleys would have contained glaciers during the Ferintosh and Jacks Stream advances and that the moraines built by the glaciers must have been over-ridden and destroyed during the Dun Fiunary advance. Thus glaciers in the valleys closer to the Main Divide reached farther during the Dun Fiunary advance than during the previous two advances, while the glaciers in valleys farther away from Main Divide did not reach as far. This, and the fact that in the more southerly valleys only rock glaciers formed in valleys which during the previous advances had nourished true glaciers, indicates that the precipitation gradient must have been steeper during the Dun Fiunary advance than during the Jacks Stream and Ferintosh advances.

\section{Acknowledgements}

I should like to thank Professors M. Gage and D. B. Lawrence, Drs. M. Kelly and A. E. Harrison, and Hr. A. Weidick, who read and commented on the manuscript at various stages; Dr. R. P. Suggate, who gave much helpful criticism; Mr. E. T. Annear, who drafted the maps; Mr. A. C. Beck, for permission to quote the date on the Macaulay peat and for help in the field; and Mr. and Mrs. G. Seymour of Ferintosh station for their hospitality.

MS. received 17 January 1967

\section{REFERENCES}

Birman, J. H. 1964. Glacial geology across the crest of the Sierra Nevada, California. Geological Society of America. Special Paper 75 .

Crandell, D. R., and Miller, R. D. I964. Post-hypsithermal glacier advances at Mount Rainier, Washington. U.S. Geological Survey. Professional Paper 50 I-D, p. Di io-i4.

Falconer, G., and others. 1965. Major end moraines in eastern and central Arctic Canada, by G. Falconer, J. D. Ives, O. H. Løken and J. T. Andrews. Geographical Bulletin (Ottawa), Vol. 7, No. 2, p. 137-53.

Harrison, A. E. 1956. Multiple glaciation since the Ice Age. Science, Vol. 124, No. 3213, p. 181-82.

Karlstrom, T. N. V. I964. Quaternary geology of the Kenai Lowland and glacial history of the Cook Inlet region, Alaska. U.S. Geological Survey. Professional Paper 443.

Kolb, A. 1958. Historische Gletscherschwankungen auf der Südhalbkugel insbesondere auf Neuseeland. SchlernSchriften. Bd. I90, p. 123-46.

Lawrence, D. B., and Lawrence, E. G. I965. Glacier studies in New Zealand. Mazama, Vol. 47, No. 13 , p. I 7-27.

McGregor, V. R. Unpublished. The geology of part of Lilybank station, South Canterbury, New Zealand. [M.Sc. thesis, University of Auckland, 1963.]

McKellar, I. C. 1955. Stranded moraines of the Hooker and Mueller Glaciers. New Zealand Journal of Science and Technology, Sect. B, Vol. 37, No. 2, p. 221-23.

Matthes, F. E. 1939. Report of Committee on Glaciers. 2oth annual meeting. Transactions of the American Geophysical Union, 1939, Pt. 4, p. $5^{18-23}$.

Østrem, G. I964. Ice-cored moraines in Scandinavia. Geografiska Annaler, Vol. 46, No. 3, p. $282-337$.

Porter, S. C. 1964. Late Pleistocene glacial chronology of north-central Brooks Range, Alaska. American Journal of Science, Vol. 262, No. 4, p. 446-6o.

Richmond, G. M. 1962. Quaternary stratigraphy of the La Sal Mountains, Utah. U.S. Geological Survey. Professional Paper 324 .

Sharp, R. P. 1960. Pleistocene glaciation in the Trinity Alps of northern California. American Journal of Science, Vol. 258 , No. 5, p. $305-40$.

Speight, J. G. 1963. Late Pleistocene historical geomorphology of the Lake Pukaki area, New Zealand. New Zealand Journal of Geology and Geophysics, Vol. 6, No. 2, p. $160-88$.

Suggate, R. P. I961. The upper boundary of the Hawera Series. Transactions of the Royal Society of New Zealand. Geology, Vol. 1, No. 3, p. 11-16.

Suggate, R. P. I965. Late Pleistocene geology of the northern part of the South Island, New Zealand. New Zealand. Geological Survey. Bulletin, New Series, 77.

Wahrhaftig, C., and Cox, A. 1959. Rock glaciers in the Alaska Range. Bulletin of the Geological Society of America, Vol. 70 , No. 4 , p. $383-436$.

Weidick, A. In press. Observations on some Holocene glacier fluctuations in West Greenland. Meddelelser om Gronland, Bd. 165, Nr. 6. 